\title{
Allogeneic GM-CSF-Based Myeloma Cell Vaccine
}

National Cancer Institute

\section{Source}

National Cancer Institute. Allogeneic GM-CSF-Based Myeloma Cell Vaccine. NCI

Thesaurus. Code C90540.

An allogeneic tumor cell vaccine containing myeloma cancer cells transfected with the granulocyte macrophage-colony-stimulating factor (GM-CSF) gene with potential antineoplastic activity. Upon vaccination, allog eneic GM-CSF-based myeloma cellular vaccine secretes GM-CSF, which may potentiate a tumor-specific cytotoxic T-lymphocyte $(\mathrm{CTL})$ response against myeloma cancer cell-associated antigens. 